\title{
The Role of Self-Esteem and Perceived Parental Mediation in Cyberbullying
}

\author{
Annisa Reginasari ${ }^{* 1}$, Tina Afiatin ${ }^{2}$, Hanif Akhtar ${ }^{3}$ \\ ${ }^{1,2}$ Faculty of Psychology, Universitas Gadjah Mada, \\ ${ }^{3}$ Faculty of Psychology, Universitas Muhammadiyah Malang
}

24 September $2018 \quad 08$ June $2021 \quad 30$ August 2021

\begin{abstract}
When access to information on the internet is expected to support the growth to adulthood, cyberbullying is instead becoming a threat to adolescents' psychological well-being. Parental mediation and self-esteem are considered as protective factors to youngsters from online risk. The present study examined whether self-esteem mediates the relationship between perceived parental mediation and cyberbullying. The study participants were 351 senior high school students in Yogyakarta, active media and internet users. The data were collected using the Cyberbullying Scale (Cronbach' $\alpha=$ $0.784)$, Self-Esteem Scale (Cronbach' $\alpha=0.766$ ), and Perceived Parental Mediation Scale (Cronbach' $\alpha=0.656$ ). Analysis using Structural Equation Modelling (SEM) showed that the proposed model reached the goodness-of-fit $\left(\chi^{2}=53.711 ; d f=18 ; p=0.001\right.$; $R M S E A=0.075 ; G F I=0.964 ; C F I=0.923)$. This study concluded that self-esteem partially mediated parental mediation and cyberbullying, with an indirect effect $=-0.047(p=0.024$; $p<0.05$ ). Self-esteem as the cognitive-personality factor and optimal parental mediation as environmental factors were considered to prevent adolescent cyberbullying. Educational, social, and clinical psychology practitioners might need to take the opportunity to involve self-esteem and parental mediation factors in intervention program design.
\end{abstract}

Keywords: cyberbullying, parental mediation, self-esteem

Cyberbullying is a new form of aggressiveness occurring in cyberspace (Li, 2007; Patchin \& Hinduja, 2006). Personal information theft (privacy), cyberbullying is also an online risk that haunts young internet users (Livingstone et al., 2018). Ideally, adolescents take advantage of the internet by accessing information about education (Gui \& Argentin, 2011) and health (E. Park \& Kwon, 2018) to support their growth and developmental transition to adulthood (Fauzia, 2018). However, adolescents can be exposed to the risk of becoming victims of cyberbullying. One in three teenagers in 30 countries, including Indonesia, reported being a victim of some forms of cyberbullying (UNICEF, 2019). Cyberbullying can create psychological pressure, depression symptoms, problematic internet use, and poor academic performance in its victims (Chang et al., 2015; Safaria, 2016). Cyberbullies, on the other hand, are potentially involved in real-world crimes (Fauzia, 2018).

Cyberbullying is a repeated aggressive action to hurt, annoy, and oppress others either implicitly or explicitly (Patchin \& Hinduja, 2006). Cyberbullies usually intentionally offensive send text messages to other parties through online platforms (Berne et al., 2013; Smith et al., 2012). Another cyberbully's criterion is anonymity (i.e., the lack of information that victim is able to validate in order to identify the person who is sending messages to them (Nasrullah, 2015; Santhoso, 2019; Tokunaga, 2010). Previous studies reveal that repetition (Nocentini et al., 2010) and publicity (the digital content is delivered and shown to some audience) are indicators of cyberbullying (Tokunaga, 2010).

Factors related to the cyberbullies' actions that come from within the individual include an academic ability (Chang et al., 2015), locus of control (Atik \& Güneri, 2013; Roberto et al., 2014), and self-esteem (Bayraktar et al., 2015; Chen et al., 2017; Mishna et al., 2016). Relational factors that play a

*Address for correspondence: annisa.reginasari@mail.ugm.ac.id 
role include parenting practiced by parents (Navarro \& Jasinski, 2013), parental mediation (Chang et al., 2015), and supervision (Atik \& Güneri, 2013). The main focus of this present study was to examine the role of self-esteem and parental mediation in the tendency of cyberbullying.

\section{Literature Review}

Self-Esteem and Cyberbullying. The role of personal factors (e.g., self-esteem) is still a controversial issue in predicting cyberbullying in adolescents. Self-esteem was unrelated to explain the actions of the bullies (Mishna et al., 2016). However, another study suggests that higher self-esteem is associated with a lower risk of becoming potential bullies (Chen et al., 2017). On the other hand, low self-esteem is a strong predictor of cyberbullying behavior (Bayraktar et al., 2015).

Perceived Parental Mediation and Cyberbullying. In the last two decades, parental mediation serves as a protective factor for children and adolescents. For example, restrictive mediation proved to decrease children's imitating the aggressive content on television (Nathanson, 1999). At the beginning of its development, the concept of parental mediation was termed television mediation, referring to the activities parents do to respond to children's interactions while watching television (Nathanson, 1999);(Nathanson, 2001). Further down the road,the parental mediation concept is applied to respond to children's activities in cyberspace- classified as active mediation, restrictive mediation, and co-using mediation (Livingstone \& Helsper, 2008). However, inconsistencies arise from the body of research. Parental control in East Asian adolescents and parental mediation (regardless of the types of mediation applied) can reduce the tendency to become perpetrators of electronic bullying (Chen et al., 2017; Shapka \& Law, 2013). In contrast, several studies have revealed that supervisory and technical parental mediations increase the child's tendency to become cyberbullies (Chang et al., 2015; Sasson \& Mesch, 2014).

Self-Esteem, Perceived Parental Mediation, and Cyberbullying. A study using multiple regression analysis showed that anonymity and parental mediation have a role in predicting adolescents' cyberbullying tendencies (Santhoso, 2019). However, multiple regression analysis technique does not provide information about measurement errors (Moulder \& Algina, 2002). Structural Equation Modeling (SEM), on the other hand, provides information that enables researchers to specify, estimate, and explain a path model that involves a mediating variable (Hox \& Bechger, 1998). The previous structural modeling studies revealed that self-esteem mediates the relationship between parental behavior (authoritative and parental control) and aggressive/antisocial behavior (Hesari \& Hejazi, 2011; Hunter et al., 2015). However, these studies still focused on investigating a general realm of parental and aggressive behavior in real life rather than on specific acts of aggression via cyber reality.

Therefore, this present study aimed to test the theoretical model of self-esteem (a cognitive-personality factor), perceived parental mediation (an environmental factor), cyberbullying (a behavioral factor), as explained by the social-cognitive theory (Bandura, 1986). The Model I (see Figure 1) adopted the path analysis model proposed by Hesari and Hejazi (2011), while model II assumed that monitoring and limiting internet use by parents are not predictors of bullying tendencies (Roberto et al., 2014).

This study hypothesized a theoretical model of the relationship between variables perceived parental and cyberbullying through self-esteem mediation fits the empirical data (see Figure 1).

\section{Method}

\section{Research Participants}

We used a purposive sampling technique to recruit research participants following these criteria: (1) Senior high school students aged 13-19 years at Yogyakarta City, living with their parents, other guardians, or separately. (2) Had previously engaged in some forms of cyberbullying, indicated by a declaration on screening form that participants have sent comments (e.g., text, images, sounds) containing jokes to mock someone on social media or group chats-based platform (i.e., Line/Blackberry 


\section{Figure 1}

Models of Mediating Role of Self-Esteem on the Relationship between Perceived Parental Mediation and Cyberbullying

\section{Model I}
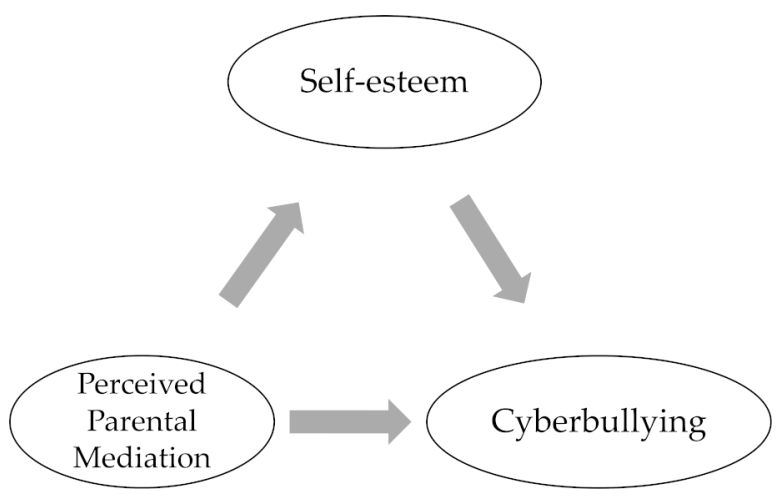

Model II
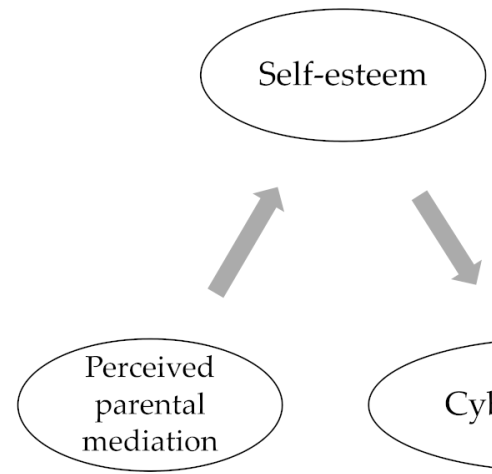

Messenger/ WhatsApp/ Twitter / Instagram / Facebook). If the students selected "never" option, they were excluded in this study.

This study involved 351 high school students in Yogyakarta city, Indonesia. This age range is the age group with the highest incidence of cyberbullying cases in Indonesia (Ruiz, 2019; Safaria, 2016; Santhoso, 2019); (UNICEF, 2019). All respondents in this study provided consent to participate in the research. The study obtained ethical approval No. 973/M.Si/X/2016; 976/M.Si/X/2016; and 873/M.Si/2016 from Ethics Committee of the Faculty of Psychology, Universitas Gadjah Mada.

\section{Data Analysis}

A total of 351 respondents were included in the data analysis as they self-reported to have anonymously sent aggressive audio-visual content to humiliate someone and then disseminated it ternet (social networking sites, e-mails, or websites). The data are part of a previous research data set (Reginasari, 2017) but was analyzed using a different technique (i.e., nonparametric cross-tabulation). This present study used a full-fledged Structural Equation Modeling (SEM) analysis with the IBM Amos version 22 software program. In addition, the modeling analysis also involved the item parceling technique by calculating the aggregate score of each variable's aspects, then served as an indicator of the structural model (Matsunaga, 2008). The indicators were grouped based on the definition of the concept and elements of each variable.

\section{Measurement}

To test content validity (Aiken V coefficient) on all of the scales (Azwar, 2016; Bashooir \& Supahar, 2018), we involved a panel of 20 judges consisting of 17 psychological scientists, two teachers, and one economics scholar. The judging panel was active students in the Master of Science and Master of Professional Psychology programs in the Faculty of Psychology, Universitas Gadjah Mada. Although the Cyberbullying Scale had been adapted for 12-13 years old adolescents (i.e., junior high school students) (Safaria, 2016), we reconstructed the scale because this present study's respondents were from older age group (i.e., high school students aged 13-19 years old).

1. Cyberbullying Scale

The Cyberbullying Scale is used to reveal the tendency to commit cyberbullying, includes intention, repetition-publicity, and anonymity elements (Berne et al., 2013); (Nocentini et al., 2010); (Smith et al., 2012); (Tokunaga, 2010). It consists of 13 items with five alternative answers ranging from very applicable to very inapplicable. This scale underwent content validation and internal consistency testing (Aiken $\mathrm{V}=0.525-0.750, r_{i x}=0.147-0.613, \alpha=0.784$ ). The higher the score the participants obtained on this scale, the higher their tendency to commit cyberbullying. Examples of items included "I sent comments to mock other people in Line/BBM/WA chat groups". 


\section{Self-esteem Scale}

Self-esteem is a globally positive or negative evaluation of one's self (Rosenberg, 1965), specifically, including one's self-acceptance and self-worth (Rosenberg et al., 1995). This present study adapted the widely-used Rosenberg's Self-Esteem Scale (Department of Sociology University of Maryland, 2019). The Self-Esteem Scale has a good content validation and internal consistency (Aiken $V=$ $0.500-0.813, r_{i x}=0.302-0.616, \alpha=0.766$ ). The Self-Esteem Scale consists of 9 reliable items with the following answer alternatives: very applicable, applicable, neutral, inapplicable, and very inapplicable. Examples of items include "I feel that I am quite worthy, at least equal to other people". The higher the scores the participants obtained on this scale, the more positive they evaluate themselves.

3. Parental Mediation Scale

Parental Mediation was measured with the Perceived Parental Mediation Scale, specifically developed to measure active, restrictive, and co-using mediation strategies. The scale was based on a series of preliminary survey studies (Reginasari, 2017) and systematic reviews of studies on the concept of parental mediation (Livingstone \& Helsper, 2008; Nathanson, 1999). The parental mediation elements were translated into behavioral indicators. The Perceived Parental Mediation Scale (7 items) considered to have a good validity, yet relatively low in internal consistency test (Aiken $\mathrm{V}=0.513-0.825, r_{i x}=0.115-0.509, \alpha=0.656$ ). The respondents could choose one of the five alternative answers including very applicable, applicable, neutral, inapplicable, and very inapplicable for each item. Examples of items include "I am encouraged by my parents to sort the images or messages that are appropriate to see from social media/Line/BBM based on their usefulness". The higher the score the respondents obtained on this scale, the higher their tendency to perceive that their parents are involved in supervising their internet media use.

\section{Results}

Of the 351 respondents, $10 \%$ were in the age group of $13-15$ years, $86.3 \%$ were adolescents aged $16-17$ years, and $3.7 \%$ were $18-19$ years old. The number of girl participants dominated (59\%) the boys $(41 \%)$. The majority of respondents lived with their parents $(88.6 \%)$, while others lived in the boarding houses $(10.8 \%)$ or independently $(0.6 \%)$.

\section{Table 1}

Mean, Standard Deviation, and Pearson Correlation Coefficient of Research Variables

\begin{tabular}{lllrrr}
\hline Variabel & Mean & SD & $\mathbf{1}$ & $\mathbf{2}$ & $\mathbf{3}$ \\
\hline 1. RundungSib & 34.934 & 6.225 & 1 & $-0.155^{* *}$ & $-0.109^{* *}$ \\
2. HargaDiri & 32.006 & 4.486 & & 1 & -0.033 \\
3. MediasiOrtu & 22.775 & 3.901 & & & 1 \\
\hline
\end{tabular}

Note. RundungSib $=$ Cyberbullying; HargaDiri $=$ Self-Esteem; MediasiOrtu $=$ Perceived Parental Mediation; $S D=$ standard deviation; ${ }^{* *} p<0.05$

Table 1 shows a significant negative correlation between cyberbullying, self-esteem, and perceived parental mediation. The Pearson correlation coefficients between observed variables (see table 2) of parental mediation strategies were relatively low, ranging from $r=0.209$ to $r=-0.249$. Fairly significant correlations were seen between elements of cyberbullying, namely between intention and repetitiveness-publicness $(r=0.528)$ and between repetitiveness-publicness and anonymity $(r=0.520)$. 
Reginasari || The Role of Self-Esteem

Table 2

Correlations between Observed Variable

\begin{tabular}{|c|c|c|c|c|c|c|c|c|}
\hline & 1 & 2 & 3 & 4 & 5 & 6 & 7 & 8 \\
\hline $\begin{array}{l}1 . \quad \text { Active } \\
\text { mediation }\end{array}$ & 1 & $.223^{* *}$ & $.249^{* *}$ & $.161^{* *}$ & $.104^{*}$ & $-.101^{*}$ & $-.206^{* *}$ & $-.158^{* *}$ \\
\hline $\begin{array}{l}\text { 2. Restrictive } \\
\text { mediation }\end{array}$ & $.223^{* *}$ & 1 & $.209^{* *}$ & $-.102^{*}$ & $-.156^{* *}$ & .008 & .020 & .000 \\
\hline $\begin{array}{l}3 . \quad \text { Co-using } \\
\text { mediation }\end{array}$ & $.249^{* *}$ & $.209^{* *}$ & 1 & .007 & .068 & -.064 & -.077 & $-.221^{* *}$ \\
\hline 4. Self-worth & $.161^{* *}$ & $-.102^{*}$ & .007 & 1 & $.572^{* *}$ & $-.154^{* *}$ & $-.131^{* *}$ & $-.099 *$ \\
\hline $\begin{array}{l}5 . \quad \text { Self } \\
\text { acceptance }\end{array}$ & $.104^{*}$ & $-.156^{* *}$ & .068 & $.572^{* *}$ & 1 & $-.162^{* *}$ & $-.104^{*}$ & $-.105^{*}$ \\
\hline 6 Intention & $-.101^{*}$ & .008 & -.064 & $-.154^{* *}$ & $-.162^{* *}$ & 1 & $.528^{* *}$ & $.366^{* *}$ \\
\hline $\begin{array}{l}\text { 7. Repetition - } \\
\text { publicity }\end{array}$ & $-.206^{* *}$ & .020 & -.077 & $-.131^{* *}$ & $-.104^{*}$ & $.528^{* *}$ & 1 & $.520^{* *}$ \\
\hline 8. Anonymity & $-.158^{* *}$ & .000 & $-.221^{* *}$ & $-.099 *$ & $-.105^{*}$ & $.366^{* *}$ & $.520^{* *}$ & 1 \\
\hline
\end{tabular}

Note. ${ }^{* *} p<0.01,{ }^{*} p<0.05$

Furthermore, there were two alternative models tested (see table 3). Indices to meet the goodness-of-fit of the model include Chi-square statistics, Root-Mean-Square Error of Approximation (RMSEA) of 0.08 or less, Goodness-of-Fit Index (GFI) (best if above 0.95), and Comparative Fit Index (CFI) (best if above 0.95) (Afiatin, 2018); (Hu \& Bentler, 1999). The analysis results showed that Model I that theorized a partial mediation model with self-esteem as the mediator and a direct path between perceived parental mediation and cyberbullying fit the data as indicated by the following index values, including $\chi^{2}=53,711 ; d f=18 ; p=0.001$; RMSEA $=0.075,90 \%$ Confidence Interval [0.053, 0.099]; GFI= 0.964; and CFI $=0.923$. Each path tested in Model I showed a significant relationship between the observed variable and the latent variable (see Figure 2).

Table 3

Comparison of Goodness-of-Fit Indices of Model I vs. Model II

\begin{tabular}{ccccccc}
\hline & $\chi^{2}$ & $\boldsymbol{d f}$ & $\boldsymbol{p}$ & $\boldsymbol{R}$ MSEA & GFI & CFI \\
\hline Model I & 53.711 & 18 & 0.000 & 0.075 & 0.964 & 0.923 \\
Model II & 63.425 & 19 & 0.000 & 0.082 & 0.958 & 0.904 \\
\hline
\end{tabular}

Note. $N=351$, RMSEA = Root-Mean-Square Error of Approximation; GFI = Goodness of Fit Index; CFI = comparative fit index

Model II which also theorized a partial mediation model with self-esteem as a mediator but with no direct path from perceived parental mediation to cyberbullying also fit the data with the following index values: $\chi^{2}=63,425 ; d f=18 ; p=0.001$; RMSEA $=0.082$; GFI $=0.958 ; \mathrm{CFI}=0.904$. From the comparison of models in Table 3, it could be inferred that model I is better than model II because Model I had a smaller RMSEA and chi-squared values than that of Model II. In Model I, the total standardized effect of perceived parental mediation on cyberbullying was $-0.336(p=0.012 ; p<0.05)$ consisting of a direct effect of $-0.290(p=0.023 ; p<0.05)$ and an indirect effect of $-0.047(p=0.024 ; p<$ $0.05)$. Meanwhile, self-esteem also affected cyberbullying with a standardized direct effect of -0.149 ( $p$ $=0.036 ; p<0.05)$.

Note.$N$ = 351; HargaDiri= Self-Esteem; MediasiOrtu= Perceived Parental Mediation; RundungSib= Cyberbullying; Penghor_Diri= Self-Worth; Pener_Diri= Self-Acceptance; Med Ak= Active Mediation; Med Bat $=$ Restrictive Mediation; Med $\mathrm{co}=\mathrm{Co}$-Using Mediation; Intensi= Intention; Repetisi-pub= Repetition-Publicity; Anon= Anonymity 
Figure 2

Model I and Model II of Mediating Role of Self-Esteem on the Relationship Between Perceived Parental Mediation and Cyberbullying

Model I

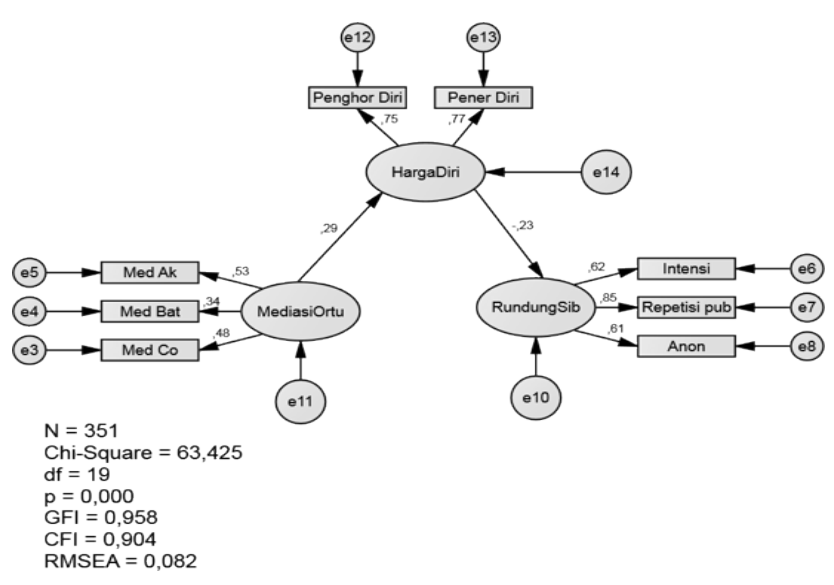

Model II

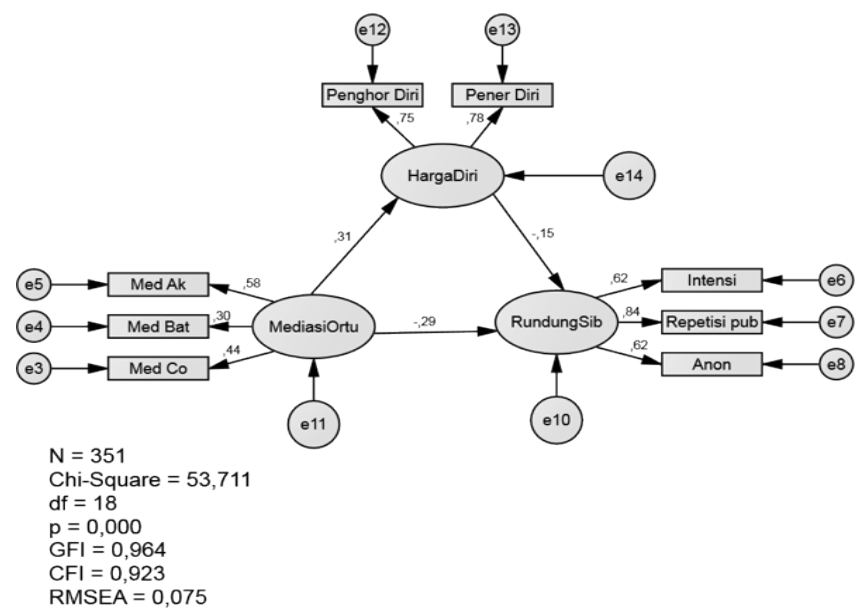

\section{Discussion}

The objective of this study was to examine the mediating effect of self-esteem on the relationship between perceived parental mediation and cyberbullying. The theoretical model that hypothesized the role of perceived parental mediation on cyberbullying through the mediation of self-esteem was supported by the empirical data. These results are consistent with the previous study which revealed that anonymity contributes to cyberbullying tendency (Santhoso, 2019). However, we determined that anonymity is an integral part of the conceptualization of cyberbullying (e.g., fair correlation between intention and repetition-publicity and between repetition-publicity and anonymity).

The presence of the self-esteem variable increases the total effect of parental mediation perceptions on cyberbullying rather than providing a direct effect. Teens with low self-esteem tend to pursuit self-worth with doubtful evaluation (Jordan \& Zeigler-Hill, 2013; L. E. Park \& Crocker, 2013). When teens doubt themselves, they turn fragile and vulnerable, which, over time, makes them more likely to become bullies (Fanti \& Henrich, 2015). An individual with fragile self-esteem tends to prove their quality via social comparisons and seeking acceptance from others (Crocker et al., 2004)).Violent behavior is an alternative means for avoiding self-doubt. In cyberspace, adolescents with vulnerable self-esteem are aware of opportunities to act anonymously and invisibly and thus free of social judgment, thereby encouraging cyberbullying behavior (Baumeister et al., 1996; Jordan \& Zeigler-Hill, 2013; L. E. Park \& Crocker, 2013; Santhoso, 2019; Suler, 2004). Conversely, a high self-esteem individual refers to the one who feels "good enough" about themselves and does not necessarily feel superior to others (Rosenberg, 1965). Despite the desire to improve themselves and overcome their limitations, they tend to see their worth with a realistic and unchanging view (i.e., a stable positive view of self) (Jordan \& Zeigler-Hill, 2013). Adolescents with this trait value themselves positively on the intrinsic domain (e.g., not using the views of others as the only measure of their positive characters) (Afiatin, 2014).

The dynamics between self-esteem and parental mediation in developing cyberbullying tendencies can be explained by the Social Cognitive Theory (Bandura, 1986). Cyberbullying tendency in adolescents can be prevented by optimizing parental mediation strategy, as an environmental factor, and cultivating positive personality factors (including self-esteem). Adolescents who perceive parental mediation positively and are strengthened by having positive (stable) self-esteem can reduce their risk of cyberbullying (Hesari \& Hejazi, 2011; Hunter et al., 2015).

Parents have an important role in encouraging their adolescent children to value themselves positively. Parents who show attention and love (i.e., active mediation) for their children and consider 
them an important part of the family would provide meaningful support for their adolescent children's self-worth (Rosenberg et al., 1995). Interpersonal experiences in the family will form the mental representation of adolescents' self when they later build relationships with other people (DeHart et al., 2013). To become a positive social environment for teenagers and young people, parents can set an example in humbleness and honesty (Afiatin, 2014; Olson et al., 2014) and mutual harmony and respect when interacting with all family members, both in the real-world context and when connected in cyberspace (Afiatin, 2018). In this present study, the active mediation strategy was quite significant in predicting the decrease in cyberbullying among adolescent respondents (Model $1=0.58$; Model II $=0.53$ ). This finding confirms that the tendency to become bullies is more likely to be found when parents involve less affection in communicating with their children, and this may lead to negative disciplinary practices (Gómez et al., 2016).

\section{Conclusions}

This study concluded that self-esteem acts as a mediator in the relationship between perceived parental mediation and cyberbullying tendency. Cognitive-personality factors (e.g., self-esteem) and environmental factors (e.g., optimal parental mediation) can prevent cyberbullying in adolescent respondents of this study.

\section{Recommendation}

The results of this study apply limitedly to the sample of respondents in this study. Reflecting the results of parental mediation construct dimensionality testing in previous studies (Livingstone \& Helsper, 2008; Nikken \& Jansz, 2014), low correlation between the factors that make up the parental mediation construct in this present study may indicate that parental mediation is a multifactor construct. Therefore, future research needs to review the dimensionality of the parental mediation construct. We would recommend practitioners of educational, social, and clinical psychology to use psychological intervention approaches that involve adolescent self-esteem factors and their relationship with factors related to parental mediation.

\section{Acknowledgments}

The researcher would like to thank the editors and reviewers who had provided suggestions, criticism, and input on this article.

\section{Funding}

The authors received no funding of any kind for this research

\section{Author's contribution}

AR was responsible for the manuscript writing, data collection, and initial data analysis. TA was responsible for providing recommendations on the theoretical framework that underlies this research. HA assisted the further data analysis, validated the drawing conclusion, and presented data in the manuscript. TA and HA have also checked the validity of the manuscript.

\section{Conflict of interest}

The authors declare no competing interests on this study

\section{Orcid id}

Annisa Reginasari 0000-0001-7411-6573

Tina Afiatin 0000-0002-7684-3042

Hanif AkhtarHanif Akhtar 0000-0002-1388-7347 
Reginasari || The Role of Self-Esteem

\section{References}

Afiatin, T. (2014). Management of family and marriage quality to create a quality young generation (Pengelolaan mutu keluarga dan perkawinan untuk mewujudkan generasi muda yang berkualitas), In Ketahanan keluarga sebagai aset bangsa, Malang, Fakultas Psikologi Universitas Merdeka Malang. https : / / acadstaff . ugm . ac . id / karya _ files / pengelolaan - mutu keluarga - dan - perkawinan - untuk - mewujudkan - generasi - muda - yang - berkualitas -3c311e9b0bd7ff9aa79b99daca124a49/8d9c68b4-f6f8-11e9-9724-e4434b0aade8

Afiatin, T. (2018). Psychology of marriage and family: Strengthening the family in the digital era based on local wisdom (Psikologi perkawinan dan keluarga: Penguatan keluarga di era digital berbasis kearifan lokal). Yogyakarta, Kanisius. https:/ /opac.perpusnas.go.id/DetailOpac.aspx?id=1137620

Atik, G., \& Güneri, O. Y. (2013). Bullying and victimization: Predictive role of individual, parental, and academic factors. School Psychology International, 34(6), 658-673. https: / / doi.org / 10.1177 / 0143034313479699

Azwar, S. (2016). Cognitive ability test construction (Konstruksi tes kemampuan kognitif). Yogyakarta, Pustaka Pelajar.

Bandura, A. (1986). Social foundations of thought and action: A social cognitive theory. New Jersey, Prentice-Hall, Inc. https:/ / psycnet.apa.org/record/1985-98423-000

Bashooir, K., \& Supahar. (2018). The validity and reliability of the STEM-based science literacy performance assessment instrument for Physics learning (Validitas dan reliabilitas instrumen asesmen kinerja literasi sains pelajaran Fisika berbasis STEM). Jurnal Penelitian dan Evaluasi Pendidikan, 22(2), 219-230. https:/ / doi.org/10.21831/pep.v22i2.20270

Baumeister, R. F., Smart, L., \& Boden, J. M. (1996). Relation of threatened egotism to violence and aggression: The dark side of high self-esteem. Psychological Review, 103(1), 5-33. https: / / doi. org /10.1037/0033-295X.103.1.5

Bayraktar, F., Machackova, H., Dedkova, L., Cerna, A., \& Ševčíková, A. (2015). Cyberbullying: The Discriminant Factors Among Cyberbullies, Cybervictims, and Cyberbully-Victims in a Czech Adolescent Sample. Journal of Interpersonal Violence, 30(18), 3192-3216. https: / / doi.org / 10. $1177 / 0886260514555006$

Berne, S., Frisén, A., Schultze-Krumbholz, A., Scheithauer, H., Naruskov, K., Luik, P., Katzer, C., Erentaite, R., \& Zukauskiene, R. (2013). Cyberbullying assessment instruments: A systematic review. Aggression and Violent Behavior, 18(2), 320-334. https://doi.org/10.1016/j.avb.2012.11. 022

Chang, F.-C., Chiu, C.-H., Miao, N.-F., Chen, P.-H., Lee, C.-M., Chiang, J.-T., \& Pan, Y.-C. (2015). The relationship between parental mediation and internet addiction among adolescents, and the association with cyberbullying and depression. Comprehensive Psychiatry, 57, 21-28. https: / / doi.org/10.1016/j.comppsych.2014.11.013

Chen, L., Ho, S. S., \& Lwin, M. O. (2017). A meta-analysis of factors predicting cyberbullying perpetration and victimization: From the social cognitive and media effects approach. New Media \& Society, 19(8), 1194-1213. https:/ / doi.org/10.1177/1461444816634037

Crocker, J., Lee, S. J., \& Park, L. E. (2004). The pursuit of self-esteem: Implication for good and evil. In The social psychology of good and evil (pp. 271-301). New York, Guilford Press.

DeHart, T., Pena, R., \& Tennen, H. (2013). The development of explicit and implicit self-esteem and their role in psychological adjustment. In Current issues in social psychology: Self-esteem (pp. 99-123). New York, Taylor \& Francis. https: / psycnet.apa.org/record/2013-15325-006

Department of Sociology University of Maryland. (2019). Self-Esteem: What Is It? Retrieved April 27, 2021, from https:/ / socy.umd.edu/about-us/rosenberg-self-esteem-scale

Fanti, K. A., \& Henrich, C. C. (2015). Effects of self-esteem and narcissism on bullying and victimization during early adolescence. The Journal of Early Adolescence, 35(1), 5-29. https://doi.org/10.1177/ 0272431613519498

Fauzia, F. (2018). Cyberbullying behaviors and impact to adolescence in Indonesia. Journal of Asian Review Public Affairs and Policy, 3(4), 49-58. 
Reginasari || The Role of Self-Esteem

Gómez, O., Romera, E. M., \& Ortega-Ruiz, R. (2016). Parenting styles and bullying: The mediating role of parental psychological aggression and physical punishment. Child Abuse and Neglect, 51, 132-143. https://doi.org/10.1016/j.chiabu.2015.10.025

Gui, M., \& Argentin, G. (2011). Digital skills of internet natives: Different forms of digital literacy in a random sample of northern italian high school students. New Media \& Society, 13(6), 963-980. https://doi.org/10.1177/1461444810389751

Hesari, N. K. Z., \& Hejazi, E. (2011). The mediating role of self esteem in the relationship between the authoritative parenting style and aggression. Procedia - Social and Behavioral Sciences, 30, 1724-1730. https://doi.org/10.1016/j.sbspro.2011.10.333

Hox, J. J., \& Bechger, T. M. (1998). An introduction to Structural Equation Modeling. Family Science Review, 11, 354-373. https://doi.org/10.1080/10705510903008345

Hu, L.-t., \& Bentler, P. M. (1999). Cutoff criteria for fit indexes in covariance structure analysis: Conventional criteria versus new alternatives. Structural Equation Modeling: A Multidisciplinary Journal, 6(1), 1-55. https://doi.org/10.1080/10705519909540118

Hunter, S. B., Barber, B. K., \& Stolz, H. E. (2015). Extending knowledge of parents' role in adolescent development: The mediating effect of self-esteem. Journal of Child and Family Studies, 24(8), 2474-2484. https://doi.org/10.1007/s10826-014-0050-1

Jordan, C. H., \& Zeigler-Hill, V. (2013). Fragile self-esteem: The perils and pitfalls of (some) high self-esteem. In Current issues in social psychology: Self-esteem (pp. 80-98). Psychology Press.

Li, Q. (2007). New bottle but old wine: A research of cyberbullying in schools. Computers in Human Behavior, 23(4), 1777-1791. https://doi.org/10.1016/j.chb.2005.10.005

Livingstone, S., \& Helsper, E. J. (2008). Parental mediation of children's internet use. Journal of Broadcasting E Electronic Media, 52(4), 581-599. https://doi.org/10.1080/08838150802437396

Livingstone, S., Mascheroni, G., \& Staksrud, E. (2018). European research on children's internet use: Assessing the past and anticipating the future. New Media and Society, 20(3), 1103-1122. https: // doi.org/10.1177/1461444816685930

Matsunaga, M. (2008). Item parceling in Structural Equation Modeling: A primer (Vol. 2). https:/ /doi.org/ $10.1080 / 19312450802458935$

Mishna, F., Khoury-Kassabri, M., Schwan, K., Wiener, J., Craig, W., Beran, T., Pepler, D., \& Daciuk, J. (2016). The contribution of social support to children and adolescents' self-perception: The mediating role of bullying victimization. Children and Youth Services Review, 63, 120-127. https: // doi.org/10.1016/j.childyouth.2016.02.013

Moulder, B. C., \& Algina, J. (2002). Comparison of methods for estimating and testing latent variable interactions. Structural Equation Modeling: A Multidisciplinary Journal, 9(1), 1-19. https:/ / doi. org/10.1207/S15328007SEM0901_1

Nasrullah, R. (2015). Perundungan siber (cyber-bullying) di status Facebook divisi Humas mabes POLRI. Jurnal Sosioteknologi, 14(1), 1-11. https://doi.org/10.5614/sostek.itbj.2015.14.1.1

Nathanson, A. I. (1999). Identifying and explaining the relationship between parental mediation and children's aggression. Communication Research, 26(2), 124-143. https: / / doi .org / 10.1177 / 009365099026002002

Nathanson, A. I. (2001). Parent and child perspectives on the presence and meaning of parental television mediation. Journal of Broadcasting \& Electronic Media, 45(2), 201-220. https: / / doi. org $/ 10.1207 / \mathrm{s} 15506878$ jobem 4502

Navarro, J. N., \& Jasinski, J. L. (2013). Women and Criminal Justice, 23(4), 286-303. https:/ / doi.org/10. $1080 / 08974454.2013 .784225$

Nikken, P., \& Jansz, J. (2014). Developing scales to measure parental mediation of young children's internet use. Learning, Media and Technology, 39(2), 250-266. https://doi.org/10.1080/17439884. 2013.782038

Nocentini, A., Calmaestra, J., Schultze-Krumbholz, A., Scheithauer, H., Ortega, R., \& Menesini, E. (2010). Cyberbullying: Labels, behaviours and definition in three european countries. Australian Journal of Guidance and Counselling, 20(2), 129-142. https:/ /doi.org/10.1375/ajgc.20. 2.129

Olson, D. H., DeFrain, J., \& Skogrand, L. (2014). Marriages \& families: Intimacy, diversity, and strengths (8th ed.). New York, McGraw-Hill Education. 
Park, E., \& Kwon, M. (2018). Health-related internet use by children and adolescents: Systematic review. Journal of Medical Internet Research, 20(4), e120. https://doi.org/10.2196/jmir.7731

Park, L. E., \& Crocker, J. (2013). Implication for self-regulation and relationships. In Current issues in social psychology: Self-esteem (pp. 43-59). New York, Psychology Press.

Patchin, J. W., \& Hinduja, S. (2006). Bullies move beyond the schoolyard. Youth Violence and Juvenile Justice, 4(2), 148-169. https:/ / doi.org/10.1177/1541204006286288

Reginasari, A. (2017). The role of self-esteem on the relationship between perceptions of parental mediation and cyber-bullying (peran harga diri pada hubungan antara persepsi mediasi orang tua dan perundungan-siber) (Master's thesis). Universitas Gadjah Mada.

Roberto, A. J., Eden, J., Savage, M. W., Ramos-Salazar, L., \& Deiss, D. M. (2014). Prevalence and predictors of cyberbullying perpetration by high school seniors. Communication Quarterly, 62(1), 97-114. https:/ / doi.org/10.1080/01463373.2013.860906

Rosenberg, M. (1965). Society and the adolescent self-image. Princeton, Princeton University Press.

Rosenberg, M., Schooler, C., Schoenbach, C., \& Rosenberg, F. (1995). Global self-esteem and specific self-esteem: Different concepts, different outcomes. American Sociological Review, 60(1), 141-156.

Ruiz, R. M. N. M. (2019). Curbing cyberbullying among students: A comparative analysis of existing laws among selected Asean countries. PEOPLE: International Journal of Social Sciences, 4(3), 1285-1305. https://doi.org/10.20319/pijss.2019.43.12851305

Safaria, T. (2016). Prevalence and impact of cyberbullying in a sample of indonesian junior high school students. Turkish Online Journal of Educational Technology, 15(1), 82-91.

Santhoso, F. H. (2019). The mediating role of parents and anonymity on students' cyberbullying tendencies (Peran mediasi orang tua dan anonimitas terhadap kecenderungan cyberbullying Siswa). Jurnal Psikologi, 46(3), 261-272. https://doi.org/10.22146/jpsi.44126

Sasson, H., \& Mesch, G. (2014). Parental mediation, peer norms, and risky online behavior among adolescents. Computers in Human Behavior, 33, 32-38. https:/ / doi.org/10.1016/j.chb.2013.12. 025

Shapka, J. D., \& Law, D. M. (2013). Does one size fit all? Ethnic differences in parenting behaviors and motivations for adolescent engagement in cyberbullying. Journal of Youth and Adolescence, 42, 723-738. https: / / doi.org/10.1007/s10964-013-9928-2

Smith, B. W., Dempsey, A. G., Jackson, S. E., Olenchak, F. R., \& Gaa, J. (2012). Cyberbullying among gifted children (B. Wallace \& G. Eriksson, Eds.). Gifted Education International, 28(1), 112-126. https://doi.org/10.1177/0261429411427652

Suler, J. (2004). The online disinhibition effect. CyberPsychology \& Behavior, 7(3), 321-326. https:/ / doi. org /10.1089/1094931041291295

Tokunaga, R. S. (2010). Following you home from school: A critical review and synthesis of research on cyberbullying victimization. Computers in Human Behavior, (3), 277-287. https: / / doi.org / 10.1016/j.chb.2009.11.014

UNICEF. (2019). UNICEF poll: More than a third of young people in 30 countries report being a victim of online bullying. 